\author{
E-ISSN $2602-2834$
}

\title{
DETERMINATION OF THE BEST FUNCTIONAL CHICKPEA CULTIVARS BY TOPSIS TECHNIQUE
}

\section{Levent Yurdaer Aydemir $『$, Fatma Gizem Akçakaya ${ }^{\circledR}$}

Cite this article as:

Aydemir, L.Y., Akçakaya, F.G. (2019). Determination of the best functional chickpea cultivars by TOPSIS technique. Food and Health, 5(4), 239-252.

https://doi.org/10.3153/FH19025

Adana Alparslan Türkeş Science and Technology University, Department of Food Engineering, Faculty of Engineering, Adana, Turkey

ORCID IDs of the authors:

L.Y.A. 0000-0003-0372-1172

F.G.A. 0000-0002-9866-0159

Submitted: 02.04 .2019

Revision requested: 10.05 .2019

Last revision received: 11.06 .2019

Accepted: 14.06.2019

Published online: 10.08 .2019

Correspondence:

Levent Yurdaer AYDEMIR

E-mail: lyaydemir@atu.edu.tr

\begin{abstract}
Technique for order preference by similarity to ideal solution (TOPSIS) analysis was firstly applied to rank the most suitable registered chickpea cultivars among $(12 \times 3=36$ samples $)$ alternatives based on their functional properties. Chickpeas were grown in controlled trial fields of state research institutes in Adana (in 2014-2015) and Erzurum (2015) regions which had mild-hot and cold climate conditions, respectively. Total phenolic (TPC) and water-soluble protein (WSPC) contents, free radical scavenging (FRSA) and iron chelating (ICA) activities, and water binding (WBC) and oil binding (OBC) capacities of extracts were determined. Equal weights were assigned for the parameters in TOPSIS application and the distances of each alternative from ideal positive and negative solution points and closeness coefficients were determined. Considerable variations were observed for TPC, FRSA and ICA. The average values of determined parameters in each group (location, year, location and year) were close to each other. Significant low positive correlations were not determined between TPC, FRSA and ICA while any significant correlations were determined between the WSPC, OBC, and WBC $(\mathrm{P}<0.05)$. Aydin cultivar had the highest score for its antioxidant and technical functions (closeness coefficient was 7.02E-01) and followed by Çakır (5.59E-01) and Azkan (4.91E-01). This study showed the suitability of TOPSIS analysis in agriculture and food science area when the sample number was high and many different properties of samples were considered.
\end{abstract}

Keywords: Chickpea, Antioxidant activity, Water absorption, Oil absorption, TOPSIS

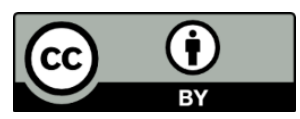

CCopyright 2019 by ScientificWebJournals Available online at

http://jfhs.scientificwebjournals.com 


\section{Introduction}

Chickpea (Cicer arientum) is one of the most important pulse crops with high carbohydrate and dietary fiber content, considerable protein content and of various minerals (Bibi et al., 2007; Özer et al., 2010; Mafakheri et al., 2011; Torutaeva et al., 2014; Çelik et al., 2016). Due to its high nitrogen utilization efficiency and high protein yield under drought conditions, chickpea is mostly grown in arid or semiarid Mediterranean environment of West Asia and North Africa and adopted in North America, western Canada, Australia, New Zealand, and Central Europe (Oweis et al., 2004; Özer et al., 2010; Ozkilinc et al., 2011; Atalay and Babaoglu, 2012; Siddique et al., 2012; Neugschwandtner et al., 2015; Sadras and Dreccer, 2015). However, there are some challenges to develop new chickpea varieties due to its restricted genetic variations, many registered cultivars have been planting around the world (Mafakheri et al., 2011; Atalay and Babaoglu, 2012; Siddique et al., 2012). Due to its suitable climatic conditions, Turkey is the fifth biggest producer of chickpea after India, Australia, Myanmar, and Ethiopia(FAO, 2012). In the market high yield registered chickpea cultivars resistant or tolerant to biotic and abiotic stress factors are being grown and consumed as flour, canned, roasted, boiled, fermented, fried steamed, or snack food (Coşkuner and Karababa, 2004; Bibi et al., 2007; Özer et al., 2010; Çelik et al., 2016). The studies also showed that chickpea seeds had good functional properties which allowed them to be used as additive in processed foods, cosmetics and pharmaceuticals. Aydemir and Yemenicioglu (2013) compared the functional properties of chickpea globulins with commercially produced soy protein isolate and concentrate, whey protein isolate, fish gelatine, bovine gelatine, and egg white protein and they reported that chickpea globulins had the potential to be used as functional protein source alternative to those commercial proteins due to their higher water and oil absorption capacities, better gelation properties, and more stable emulsion and foam formation abilities (Aydemir and Yemenicioglu, 2013). Chickpea extracts had also showed considerable antioxidant activity based on free radical scavenging and metal chelating properties which were associated with better food quality protection and health benefits (Zhao et al., 2014; Kou et al., 2015; Torres-Fuentes et al., 2015).

In this study functional properties of 12 registered chickpea cultivars were grown in different locations in different growing seasons were determined. Although the climate conditions and seasonal variances were highly effective on physical and chemical properties on the same cultivars, it was aimed to determine the best cultivars with high functional properties. 6 different criteria were determined and measured associated with the functional properties of chickpeas but to evaluate the results was difficult because one sample might be preferred regarding one functional property (such as antioxidant activity), the other sample might be preferred considering the other functional property (such as water absorption capacity) (Ozturk et al., 2014). In order to overcome this difficulty, multi criteria decision methods could be applied to evaluate the results and to determine the best cultivars which had different functional properties. Multi criteria decision methods are used for the evaluation of alternatives based on determined criteria by using a number of qualitative and/or quantitative criteria (Özcan et al., 2011). Different types of multi criteria decision methods have been applied in different studies and among them TOPSIS (technique for order preference by similarity to ideal solution) technique is one of methods which is widely used to obtain decision hierarchy by making pairwise comparison between criteria. In TOPSIS method, positive and negative ideal solutions are calculated, and the best alternative is determined which is nearest to the positive ideal solution and farthest from the negative ideal solution (Lin et al., 2008; Balli and Korukoglu, 2009). Although TOPSIS technique have been extensively used in many different areas (management, computer, electrical sciences, etc.), only a few numbers of studies using this technique are found in food science literature. Mostly researchers used TOPSIS technique for optimization of new food formulations such as cheese nuggets, vegetable juice, prebiotic pudding, hot chocolate beverage, and milk based herbal tea. (Gurmeric et al., 2013; Ozturk et al., 2014; Ansarifar et al., 2015; Dogan et al., 2016, 2018; Gul and Dervisoglu, 2017). Kou et al., (2015) and Sun et al., (2011) were also applied TOPSIS technique to determine the best alternatives among different jujube cultivars based on their bioactive properties such as phenolic content or antioxidant activity (Sun et al., 2011; Kou et al., 2013).

In this study TOPSIS technique was applied to determine the best registered chickpea cultivars among 36 samples with high functional properties such as free radical scavenging and iron chelating activity, water and oil binding capacity, soluble protein content and total phenolic content which were grown in two different locations (Adana and Erzurum) or two different years (2014 and 2015).

\section{Materials and Methods}

\section{Materials}

12 registered chickpea seeds were kindly provided from Dr. Dürdane Mart from Eastern Mediterranean Agricultural Research Institute, Adana, TURKEY. Registered chickpea cultivars were abbreviated as follow: Aksu, Arda, Aydın, Azkan, Çakır, Diyar, Gülümser, Hasanbey, Ilgaz, İzmir, İnci, Seçkin 
as AK, AR, AY, AZ, CA, DI, GU, HA, IL, IZ, IN, SE, respectively. Location of Adana and Erzurum were abbreviated as A and E while grown year of 2014 and 2015 were abbreviated as 14 and 15 as suffix for cultivar name, respectively. Example: AKA14 was an abbreviation AKSU-ADANA2014 that meant Aksu cultivar grown in Adana location in 2014. The chemicals used in the study were listed as Folin Ciocalteu's reagent, $\mathrm{K}_{2} \mathrm{O}_{8} \mathrm{~S}_{2}, \mathrm{NaH}_{2} \mathrm{PO}_{4}, \mathrm{Na}_{2} \mathrm{HPO}_{4}, \mathrm{NaCl}$, $\mathrm{Na}_{2} \mathrm{CO}_{3},( \pm)$-6-Hydroxy-2,5,7,8-tetramethylchromane-2-carboxylic acid (trolox), 3-(2-Pyridyl)-5,6-diphenyl-1,2,4-triazine-p,p'-disulfonic acid monosodium salt hydrate (FerroZine) and $\mathrm{FeCl}_{2}$ which were purchased from Merck KGaA (Germany), and ethylene diamine tetraacetic acid (EDTA), $\mathrm{CuSO}_{4}, \mathrm{Na}-\mathrm{K}$ tartrate, $\mathrm{NaOH}$, gallic acid, sodium caseinate, 2, 2'-Azino-bis (3-ethyl benzothiazoline-6-sulfonic acid) diammonium salt (ABTS) which were purchased from SigmaAldrich (Germany).

\section{Determination of Water and Oil Binding Capacity of Chickpea Flours}

The water (WBC) and oil binding capacities (OBC) of chickpea flour were determined by interacting $50 \mathrm{mg}$ of chickpea flour and $1.5 \mathrm{~mL}$ of liquid (distilled water or commercial sunflower oil) for 30 minutes at room temperature after mixing in a test tube for 20 seconds. After incubation, free liquid phase was separated by centrifugation $\left(15000 \times \mathrm{g}, 25^{\circ} \mathrm{C}, 20\right.$ min) (Aydemir et al., 2014). The absorbed liquid content was calculated as average of three measurement and WBC and OBC of flour samples were expressed as g liquid/g dry weight flour. Total moisture content of chickpea flours was measured with moisture analyser (Ohaus MB 45, Switzerland).

\section{Preparation of Water Soluble Chickpea Extracts}

$500 \mathrm{mg}$ of chickpea flour were stirred in $5 \mathrm{~mL}$ deionized water in orbital shaker overnight about $18-20$ hours at $25{ }^{\circ} \mathrm{C}$ to maximize the extraction of water soluble components in chickpea flour ( $\mathrm{pH}$ of the solution was $6.5 \pm 0.2$ ). Then the suspensions were centrifuged, and clear supernatants were separated and named as chickpea soluble extract $(15000 \times \mathrm{rcf}$, $25^{\circ} \mathrm{C}, 30 \mathrm{~min}$ ) (Aydemir et al., 2014).

\section{Determination of Water Soluble Protein Content of Chickpea Extracts}

The water-soluble protein content (WSPC) of chickpea extracts was spectrophotometrically determined by using Lowry method (Lowry et al., 1951). $0.2 \mathrm{~mL}$ of chickpea extract were reacted with $2.1 \mathrm{~mL}$ of Lowry reactive for $10 \mathrm{~min}$. Lowry reactive was prepared with $245 \mathrm{~mL}$ of $2 \%(\mathrm{w} / \mathrm{v})$ $\mathrm{Na}_{2} \mathrm{CO}_{3}, 2.5 \mathrm{~mL}$ of $1 \%(\mathrm{w} / \mathrm{v}) \mathrm{CuSO}_{4} .5 \mathrm{H}_{2} \mathrm{O}$ and $2.5 \mathrm{~mL} 1 \%$ (w/v) Na-K tartrate dissolving in $0.1 \mathrm{~mol} / \mathrm{L} \mathrm{NaOH}$ solution. Then $0.2 \mathrm{~mL}$ of 10 -fold diluted Folin Ciocalteu's reagent was added into the mixture and further incubated for 1 hour at ambient temperature in dark conditions. The absorbances of the test samples were determined at $750 \mathrm{~nm}$ and WSPC results as average of three different sample measurements were expressed as sodium caseinate equivalents ( $\mathrm{mg}$ of caseinate / $\mathrm{g}$ dry seed).

\section{Determination of Total Phenolic Content of Chickpea Extracts}

Total phenolic content (TPC) of chickpea extracts were determined spectrophotometrically by using Folin Ciocalteu's reagent as described by Aydemir et al. (2013) (Aydemir and Yemenicioglu, 2013). Firstly, $400 \mu \mathrm{L}$ of chickpea extract were reacted with $1000 \mu \mathrm{L}$ of 10 -fold diluted Folin Ciocalteu's reagent (in distilled water) for 3 minutes and then 800 $\mu \mathrm{L}$ of $7.5 \%(\mathrm{w} / \mathrm{v}) \mathrm{Na}_{2} \mathrm{CO}_{3}$ were added into the mixture and further incubated for 2 hours at room temperature in dark conditions. The absorbances of the test samples were determined at $765 \mathrm{~nm}$ and TPC results as average of three different sample measurements were expressed as gallic acid equivalents ( $\mu \mathrm{g}$ of GA/g dry seed).

\section{Determination of Free Radical Scavenging Activity of Chickpea Extracts}

The free radical scavenging activity (FRSA) of chickpea extract was spectrophotometrically determined by measuring the inhibition of ABTS radical cations by antioxidants in chickpea extract for 6 minutes (Re et al., 1999). Firstly, 7 mmol/L ABTS radical solution was prepared by dissolving ABTS in $2.45 \mathrm{mmol} / \mathrm{L} \mathrm{K}_{2} \mathrm{O}_{8} \mathrm{~S}_{2}$ and left for incubation about $16-18 \mathrm{~h}$ at room temperature in dark conditions. Before the tests, absorbance of the solution was set $0.700 \pm 0.020$ at 734 $\mathrm{nm}$ diluting with $75 \mathrm{mmol} / \mathrm{L}$ phosphate buffer saline containing $150 \mathrm{mmol} / \mathrm{L} \mathrm{NaCl}, \mathrm{pH} 7.4$. Then, $0.1 \mathrm{~mL}$ chickpea extract was reacted with $1.9 \mathrm{~mL}$ ABTS radical solution and the absorbance of the mixture was read at $6^{\text {th }}$ minutes. The $\%$ inhibition of ABTS radical cation was determined by calculating the differences between absorbance read at $6^{\text {th }}$ min and absorbance set for the ABTS solution. The FRSA results of the test samples were average of three different sample measurements and were expressed as trolox equivalents ( $\mu \mathrm{mol}$ Trolox/g dry seed).

\section{Determination of Iron Chelating Activity of Chickpea Extracts}

The iron chelating activity (ICA) of chickpea extract was spectrophotometrically determined according to the method described in Aydemir et al. (2014) (Aydemir et al., 2014). Firstly, $2 \mathrm{~mL}$ of chickpea extract was reacted with $0.1 \mathrm{~mL}$ of $1 \mathrm{mmol} / \mathrm{L} \mathrm{FeCl}_{2} .4 \mathrm{H}_{2} \mathrm{O}$ solution and for 30 minutes at room temperature in dark conditions. Then, $0.1 \mathrm{~mL}$ of $0.5 \mathrm{mmol} / \mathrm{L}$ 
ferrozine was added into the solution and further incubated for 10 minutes. The absorbance of test samples was determined at $562 \mathrm{~nm}$ and ICA results of average of three different sample measurements were expressed as EDTA equivalents ( $\mu$ mol of EDTA/g dry seed).

\section{TOPSIS Comprehensive Evaluation Method}

TOPSIS method was applied to determine the best chickpea samples based on grown location, grown year, and all samples (Ozturk et al., 2014). The steps of TOPSIS method were as follow: In step 1, the normalized decision matrix was established by the following equation

$$
\begin{aligned}
& x_{-} i j=a_{-} i j / \sqrt{ }\left(\sum_{-}(k=1)^{\wedge} m a j_{-} k j^{\wedge} 2\right)(1) \\
& \mathrm{k}=1,2,3 \ldots, \mathrm{i}, \ldots, \mathrm{k}, \quad \mathrm{i}=1,2, \ldots
\end{aligned}
$$

where $x_{i j}$ is the normalized value and $a_{i j}$ is the real value of the criteria. In step 2, the weighted normalized decision matrix was calculated using the following equation

$v_{i j}=x_{i j} \times w_{i j}$

where $v_{i j}$ is the weighted normalized value and $w_{i j}$ is the weight of the criteria. In this study equal weight was assigned for each criteria. In step 3, the positive and negative ideal solutions are determined

$S^{*}=\left\{v_{1 *}, v_{2 *}, v_{3 *}, \ldots, v_{n *}\right\}$ (maximum values)

$S^{-}=\left\{v_{1-}, v_{2-}, v_{3-}, \ldots, v_{n-}\right\}$ (minimum values)

In step 4 , the distance of each alternative from the positive and negative ideal solution is calculated according to the following equations

$d_{i}^{*}=\sqrt{\left(v_{i j}-v_{j}^{*}\right)^{2}}$

$d_{i}^{-}=\sqrt{\left(v_{i j}-v_{j}^{-}\right)^{2}}$

where $d_{i}^{*}$ and $d_{i}^{-}$is the distance of alternative from positive and negative ideal solution, respectively. In step 5, the closeness coefficient of each alternative $(C)$ is obtained using following equation

$C=\left(d_{-} i^{\wedge}-\right) /\left(d_{-} i^{\wedge} *+d_{-} i^{\wedge}-\right)$

In step 6 , the ranking of alternatives is determined based on their $C$ values.

\section{Statistical Analysis}

Analysis of variances (ANOVA) and correlations were done using by Minitab 17 software (Minitab Ltd., United Kingdom).

\section{Results and Discussion}

\section{Functional Properties of Chickpea Cultivars}

Registered chickpea cultivars were grown in Adana and Erzurum regions which had mild and cold climate conditions, respectively. Annual average temperature and total rainfall were $18.9^{\circ} \mathrm{C}$ and $646.6 \mathrm{~mm}$ in Adana and (1927-2016); 5.7 ${ }^{\circ} \mathrm{C}$ and $432.8 \mathrm{~mm}$ for Erzurum (1929-2016). In Adana region, the chickpeas were grown in 2014 and 2015 while for Erzurum region the harvest year was only 2015. The growth of chickpeas in Adana region in successive years provided the chance of better comparison of some functional properties of chickpea cultivars by minimizing the effects of harvest year variations on functional properties while the growth of chickpeas in Adana and Erzurum regions at the same year provided the chance of better comparison of those properties by minimizing the effects of harvest location and climate variations. On the other hand, these conditional differences also gave the opportunity to determine the effects of different harvest locations and years on considered properties of chickpea cultivars.

The chickpea extracts used in the study were obtained by using water as a solvent. Generally organic solvents such as methanol, ethanol, acetone, or their aqueous solutions are used for sample extractions to determine phenolic content and antioxidant activity because organic solvents provide better phenolic extractions from food samples and mostly those phenolic compounds are the main contributors to the antioxidant activity of that food sample. However, organic solvents provide better phenolic extraction they require additional steps and increase cost in food processing since organic solvents should be completely removed from food extracts by evaporating, drying, etc. due to toxicity for human health and being not acceptable for food industry (Durante et al., 2014; Hou et al., 2016). Therefore, deionised water was used as sole solvent in this study. The production of water soluble chickpea extracts was also easy, cheap, and completely safe. In addition, to interpret data obtained from analysis were closer to the potential real food process applications. The previous study conducted our group has also reported that water extraction of chickpea samples yielded more total phenolic content than the samples extracted by ethanol, acetone, and acidified acetone (Diblan et al., 2018). In that study, it was seen that Folic-Ciocalteu method measured more phenolic contents in water extracts of legumes than organic extracts since the water soluble proteins made contribution to the results due to their amino acid residues containing aromatic ring. The bands belonging soluble proteins were only determined in water extracts in legumes according the FT-IR characteriza- 
tion. Moreover, some phenolic compounds can be found either free or complexed form with proteins. When the water extraction was applied to the legumes, protein-phenolic complexes might become soluble in water extracts which were not be soluble in organic extracts.

Considerable variations in each parameter were determined between the cultivars in Adana 2014, Adana 2015, and Erzurum $2015(\mathrm{P}<0.05)$. The differences between chickpea extracts were broader in their TPC, ICA and FRSA values which were more associated with antioxidant activity. Antioxidant in legumes had the potential to be used as additive in food formulas to prevent lipid oxidation and food supplement (Escarpa and Gonzalez, 2001). On the other hand, less variations between chickpea extracts were determined in their WSPC, WBC, and OBC values which were more associated with their technological properties during food processing because these properties are related to their foaming, emulsifying and gelling properties (Aydemir and Yemenicioglu, 2013). The average values of TPC, ICA, FRSA, WSPC, WBC, and OBC of chickpea seeds grown in Adana 2014 were $1955 \pm 260 \mu \mathrm{g} \mathrm{GA} / \mathrm{g}, 13.0 \pm 4.7 \mu \mathrm{mol}$ EDTA/g, $20.4 \pm 3.8$ $\mu \mathrm{mol}$ Trolox $/ \mathrm{g}, 72 \pm 5 \mathrm{mg}$ caseinate $/ \mathrm{g}, 2.88 \pm 0.38 \mathrm{~g} / \mathrm{g}$, and $0.95 \pm 0.19 \mathrm{~g} / \mathrm{g}$; those of grown in Adana 2015 were 1875 $\pm 220 \mu \mathrm{g} \mathrm{GA} / \mathrm{g}, 9.5 \pm 5.4 \mu \mathrm{mol}$ EDTA $/ \mathrm{g}, 19.9 \pm 2.2 \mu \mathrm{mol}$ Trolox $/ \mathrm{g}, \quad 61 \pm 9 \mathrm{mg}$ caseinate $/ \mathrm{g}, \quad 2.85 \pm 0.34 \mathrm{~g} / \mathrm{g}$, and $0.88 \pm 0.12 \mathrm{~g} / \mathrm{g}$; those of grown in Erzurum 2015 were 1930 $\pm 214 \mu \mathrm{g} \mathrm{GA} / \mathrm{g}, 11.5 \pm 3.2 \mu \mathrm{mol}$ EDTA/g, $21.5 \pm 2.7 \mu \mathrm{mol}$ Trolox $/ \mathrm{g}, 67 \pm 8 \mathrm{mg}$ caseinate $/ \mathrm{g}, 2.47 \pm 0.31 \mathrm{~g} / \mathrm{g}$, and 0.96 $\pm 0.17 \mathrm{~g} / \mathrm{g}$, respectively. AYA14 cultivar was one of the prominent chickpea samples with its high TPC, ICA, FRSA and WSPC values $(\mathrm{P}<0.05)$. According to ANOVA results, chickpea samples grown in Adana 2014 had better functional properties than those of cultivars grown in Adana and Erzurum 2015. On the other hand, the lowest functional properties were mostly owned by the cultivars grown in Adana 2015. Any statistical differences were not observed between the average values of each criterion had by chickpea extracts when classified as Adana 2014, Adana 2015 and Erzurum 2015 $(\mathrm{P}<0.05)$. When the functional properties of chickpea extracts were evaluated for their harvest location and harvest year, the variations between the cultivars in each criterion were decreased even any statistical differences were not observed in WBC of chickpea cultivars grown in $2015(\mathrm{P}<0.05)$. This situation made more difficult to decide the best cultivars with good functional properties. Because the functional property values of chickpea extracts were similar to each other and between these values significant differences mostly did not observed. Diblan et al., (2018) investigated the effects of different solvents on TPC of chickpea extracts and reported that water extraction provided the highest phenolic content (1829 $\pm 12 \mu \mathrm{g} \mathrm{GAE} / \mathrm{g}$ that was similar to our findings) than ethanol
$(1478 \pm 79 \mu \mathrm{g} \mathrm{GAE} / \mathrm{g})$, acetone $(875 \pm 21 \mu \mathrm{g} \mathrm{GAE} / \mathrm{g})$ and acidified acetone $(729 \pm 24 \mu \mathrm{g}$ GAE/g) extraction methods (Diblan et al., 2018). Arab, Helmy, and Bareh (2010) measured the WBC and OBC of chickpea flours to be used in functional pasta production and determined the similar $\mathrm{OBC}$ values but lower WBC values than our findings (Arab et al., 2010). It is common to see some differences in functional properties of chickpea flours due to cultivar variations. In the literature mostly, aqueous organic solvents such as methanol, ethanol, acetone, hexane, etc. were mostly used for chickpea extraction. The reported TPC values were between 0.45 and $10.84 \mathrm{mg} \mathrm{GAE} / \mathrm{g}$ flour which were similar to our findings and FRSA were $1.26 \pm 0.09 \mu \mathrm{mol} \mathrm{TE} / \mathrm{g}, 31.4 \pm 1.4 \mu \mathrm{g} / \mathrm{mL}\left(\mathrm{IC}_{50}\right)$, and $22.85 \pm 0.25$ (\% inhibition) which were the lower than our findings (Sreerama et al., 2012; Jogihalli et al., 2017; Rocchetti et al., 2017; Xu et al., 2017). OBC of registered cultivar flours were similar to the results reported in the literature whereas $\mathrm{WBC}$ were found mostly higher than those of literature. $\mathrm{OBC}$ was varied from 0.85 to $1.25 \mathrm{~g} / \mathrm{g}$ and WBC was between 0.89 and $2.30 \mathrm{~g} / \mathrm{g}$ (Kaur and Singh, 2005; Joshi et al., 2007; Xu et al., 2014, 2017; Jogihalli et al., 2017). Unfortunately, metal chelating activity of chickpea flour extract could not be obtained from the reachable literature. Some studies were also investigated the functional properties of chickpea proteins where the water was used for protein extraction (Arcan and Yemenicioglu, 2007, 2010; Yust et al., 2010; Aydemir and Yemenicioglu, 2013; Mokni Ghribi et al., 2015; Torres-Fuentes et al., 2015; Jogihalli et al., 2017). For chickpea protein extraction, alkali conditions were generally created by using chemicals such as $\mathrm{NaOH}, \mathrm{KOH}$, etc. and additional centrifugation steps and drying processing (lyophilization) were employed. Aydemir and Yemenicioglu (2013) determined the TPC, WSPC, WBC, and OBC of four different chickpea globulin proteins (Aydemir and Yemenicioglu, 2013). They found that chickpea proteins had higher TPC, $\mathrm{WBC}$ and $\mathrm{OBC}$ by 4, 2, and 14 times. Arcan and Yemenicioglu (2007) applied heat treatment to chickpeas to determine the effect of heat to the antioxidant properties of chickpeas and measured FRSA and ICA values of protein extracts. The measured values were considerably higher than our values because antioxidant proteins were concentrated on chickpea proteins due to bound phenolics and electron transferring groups on amino acids to free radicals (Arcan and Yemenicioglu, 2007).

In order to determine the best chickpea cultivars with good functional properties, 36 alternatives were ranked based on each functional criterion. The rankings were completely different from each other. The first three rankings for TPC was DIA14, AYA14, AYE15; for ICA was AYA14, AZA15, DIA14; for FRSA was ILE15, DIA14, AYA14; for WSPC was AYA14, AYE15, SEA15; for WBC was HAA14, 
AKA15, ILA15; for OBC was CAE15, ARA14, ARE15. This ranking which had 36 alternatives in each criterion made the decision more difficult because in practical application the main objective of this breeding program was to test the chickpea cultivars in different growing conditions such as location and year. Among tested cultivars, high quality and productive samples would be chosen and announced as the primary cultivars to be grown. For this reason, it looked more economical to choose the cultivars that can be grown in different conditions with high quality. The functional properties analysed in this study were the tools that might attach higher importance to the cultivars for value added product production such as natural additive, food supplement or etc.

For this reason, a new ranking of 12 registered cultivars were done by using the average values of the same chickpea cultivar for each criterion (for example: average value of Aksu cultivar in TPC criterion was calculated by averaging TPC of Aksu extract in Adana 2014, Adana 2015, and Erzurum 2015). However, Aydin cultivar had the first rank in TPC, ICA, FRSA, and WSPC, it was still difficult to decide the best cultivars because the rankings were again completely different in each criterion. It was Aydın, Diyar, Gülümser for TPC; Aydın, Azkan, Çakır for ICA; Aydın, Diyar, Azkan for FRSA; Aydın, Seçkin, Ilgaz for WSPC; Hasanbey, Ilgaz, İzmir for WBC; and Çakır, İnci, Arda for OBC. All of these challenges were considered, the best way was to apply one of the multi criteria decision techniques to decide the best cultivars with good functional properties.

\section{TOPSIS Comprehensive Evaluation for Ranking Cultivars}

In order to determine the best chickpea cultivars with good functional properties, TOPSIS, multi criteria decision technique, was applied for 12 alternatives considering 6 criteria. Alternatives were the cultivars: Aksu, Arda, Aydın, Azkan, Çakır, Diyar, Gülümser, Hasanbey, Ilgaz, İnci, İzmir, and Seçkin. Criteria were TPC, ICA, FRSA, WSPC, WBC, and OBC. The TOPSIS evaluation were used for three purposes: to determine the best cultivars (alternatives) grown in i) only Adana region, ii) in 2015, iii) all location and harvest years. The average values of the same chickpea cultivars grown in different location and years were calculated. After decision matrix was constructed, the normalized decision matrix was constructed (Table 1). This technique gives the researcher the advantage of being involved in the analysis process by assigning "weight" to the criteria considering the importance of the criteria. In this study equal weights were assigned to each criterion as 0.17 (total weight should be 1.00 for 6 criteria). Because it was aimed to determine the best chickpea cultivars which were good at in all functional properties. However, different weights could be assigned according to the purposes.
For example, if someone aimed to determine the cultivars good at more antioxidant properties, the weights would be assigned higher for FRSA, ICA, and TPC than WSPC, WBC, OBC. On the other hand, if the aim was to determine the cultivars good at more technological properties such as WSPC, $\mathrm{WBC}$, and $\mathrm{OBC}$, the higher weights would be assigned for these criteria than TPC, ICA, FRSA. The weighted normalized decision matrix was given in Table 2. According to the weighted normalized decision matrix, positive $\left(\mathrm{S}^{*}\right)$ and negative $\left(\mathrm{S}^{-}\right)$ideal solutions for each criterion were determined in Table 3. These ideal solutions were important for TOPSIS technique because the distances of alternatives (chickpea cultivars) from these points are used in the analysis to rank the alternatives. The being closest to the positive ideal solution and farthest to the negative ideal solution were associated with the closeness coefficient of alternatives (Table 4). According to the closeness coefficient of alternatives, the first three rank was Aydın, Azkan, and Çakır cultivars among those grown in only Adana region (closeness coefficients varied from 1.75E-01 to 7.02E-01); Çakır, Seçkin, Azkan cultivars among those grown in 2015 (closeness coefficients varied from 1.89E-01 to 7.33E-01); Aydın, Çakır, and Azkan cultivars among those all grown in all locations and harvest years (closeness coefficients varied from 1.75E-01 to 7.02E$01)$. According to three TOPSIS analysis, İnci and Gülümser cultivars were the worst samples with the lowest closeness coefficients.

However, many decision problems including multi criteria have been encountered in food science area, it is not very common to use multi criteria decision techniques to solve the problems. In food science, the researchers were benefited from TOPSIS technique in food for either optimization of new food formulations or to determine the best alternatives among the samples (Gurmeric et al., 2013; Ozturk et al., 2014; Ansarifar et al., 2015; Dogan et al., 2016, 2018; Gul and Dervisoglu, 2017). Similar to our study, Kou et al. (2015) applied TOPSIS technique to evaluate the nutrition of 15 different jujube cultivars (alternatives) based on their total flavonoids, proanthocyanidins, ascorbic acid, total triterpene, total polyphenol, total polysaccharide, cAMP (7 criteria) values and reported that TOPSIS technique was an efficient ranking method (Kou et al., 2015). Sun et al. (2011) ranked the 10 batches of sour jujube fruits based on their polyphenols, flavonoids, anthocyanins, saponins, alkaloids, polysaccharides, carotenoids, vitamin $\mathrm{C}$ and selenium contents and concluded that TOPSIS method can be efficiently utilised in the assessment of total natural antioxidant content and quality of sour jujube fruits (Sun et al., 2011). 
Table 1. Normalized decision matrix

\begin{tabular}{|c|c|c|c|c|c|c|}
\hline Alternatives & TPC & ICA & FRSA & WSPC & WBC & OBC \\
\hline \multicolumn{7}{|c|}{ All samples } \\
\hline Aksu & 0.2828 & 0.2409 & 0.2767 & 0.2727 & 0.2850 & 0.2300 \\
\hline Arda & 0.2884 & 0.2788 & 0.3037 & 0.2619 & 0.2914 & 0.3202 \\
\hline Aydın & 0.3201 & 0.4254 & 0.3051 & 0.3302 & 0.2663 & 0.2732 \\
\hline Azkan & 0.2804 & 0.3591 & 0.3041 & 0.2595 & 0.2789 & 0.2421 \\
\hline Çakır & 0.2811 & 0.3168 & 0.2655 & 0.2840 & 0.2943 & 0.3567 \\
\hline Diyar & 0.3146 & 0.2795 & 0.3048 & 0.2922 & 0.2653 & 0.2811 \\
\hline Gülümser & 0.3083 & 0.2133 & 0.2976 & 0.2901 & 0.2725 & 0.3046 \\
\hline Hasanbey & 0.2674 & 0.2333 & 0.2723 & 0.2834 & 0.3262 & 0.2698 \\
\hline Ilgaz & 0.2895 & 0.2609 & 0.2862 & 0.2967 & 0.3114 & 0.2564 \\
\hline İnci & 0.2771 & 0.2233 & 0.3001 & 0.2955 & 0.2932 & 0.3283 \\
\hline İzmir & 0.2533 & 0.2993 & 0.2570 & 0.2721 & 0.3040 & 0.2965 \\
\hline Seçkin & 0.2942 & 0.2616 & 0.2855 & 0.3175 & 0.2685 & 0.2795 \\
\hline \multicolumn{7}{|c|}{ Adana in 2014 and 2015} \\
\hline Aksu & 0.2685 & 0.2583 & 0.2689 & 0.2648 & 0.3165 & 0.2401 \\
\hline Arda & 0.2952 & 0.3156 & 0.3026 & 0.2639 & 0.3016 & 0.3028 \\
\hline Aydın & 0.3112 & 0.4387 & 0.3064 & 0.3289 & 0.2593 & 0.2790 \\
\hline Azkan & 0.2796 & 0.4225 & 0.3110 & 0.2656 & 0.2792 & 0.2653 \\
\hline Çakır & 0.2817 & 0.3344 & 0.2496 & 0.2700 & 0.2758 & 0.3476 \\
\hline Diyar & 0.3310 & 0.2731 & 0.3041 & 0.3027 & 0.2675 & 0.2815 \\
\hline Gülümser & 0.3031 & 0.1387 & 0.2967 & 0.2778 & 0.2764 & 0.3290 \\
\hline Hasanbey & 0.2741 & 0.1881 & 0.2910 & 0.2685 & 0.3265 & 0.2659 \\
\hline Ilgaz & 0.2821 & 0.1975 & 0.2615 & 0.3034 & 0.3210 & 0.2392 \\
\hline İnci & 0.2793 & 0.2441 & 0.3061 & 0.2803 & 0.2896 & 0.3310 \\
\hline İzmir & 0.2694 & 0.2464 & 0.2879 & 0.2929 & 0.2924 & 0.2904 \\
\hline Seçkin & 0.2823 & 0.2496 & 0.2702 & 0.3336 & 0.2462 & 0.2688 \\
\hline \multicolumn{7}{|c|}{ Adana and Erzurum in 2015} \\
\hline Aksu & 0.2692 & 0.1640 & 0.2575 & 0.2781 & 0.2915 & 0.2320 \\
\hline Arda & 0.2952 & 0.2445 & 0.3183 & 0.2431 & 0.2928 & 0.2995 \\
\hline Aydın & 0.3058 & 0.4121 & 0.2877 & 0.3271 & 0.2583 & 0.2705 \\
\hline Azkan & 0.2609 & 0.3492 & 0.2881 & 0.2462 & 0.2770 & 0.2172 \\
\hline Çakır & 0.3047 & 0.3325 & 0.2822 & 0.3025 & 0.3007 & 0.3632 \\
\hline Diyar & 0.2939 & 0.2128 & 0.2829 & 0.2878 & 0.2562 & 0.3017 \\
\hline Gülümser & 0.3188 & 0.2038 & 0.2894 & 0.2877 & 0.2785 & 0.2808 \\
\hline Hasanbey & 0.2795 & 0.2825 & 0.2729 & 0.2790 & 0.2918 & 0.2768 \\
\hline Ilgaz & 0.2893 & 0.3092 & 0.3104 & 0.3013 & 0.3095 & 0.2725 \\
\hline Ínci & 0.2882 & 0.1317 & 0.3045 & 0.3066 & 0.2996 & 0.3175 \\
\hline İzmir & 0.2374 & 0.3451 & 0.2552 & 0.2683 & 0.3110 & 0.2813 \\
\hline Seçkin & 0.3111 & 0.3352 & 0.3075 & 0.3228 & 0.2912 & 0.3218 \\
\hline
\end{tabular}


Table 2. Weighted normalized decision matrix

\begin{tabular}{|c|c|c|c|c|c|c|}
\hline Alternatives & TPC & ICA & FRSA & WSPC & WBC & OBC \\
\hline \multicolumn{7}{|c|}{ All samples } \\
\hline Aksu & 0.0471 & 0.0401 & 0.0461 & 0.0454 & 0.0475 & 0.0383 \\
\hline Arda & 0.0481 & 0.0465 & 0.0506 & 0.0436 & 0.0486 & 0.0534 \\
\hline Aydın & 0.0533 & 0.0709 & 0.0509 & 0.0550 & 0.0444 & 0.0455 \\
\hline Azkan & 0.0467 & 0.0599 & 0.0507 & 0.0432 & 0.0465 & 0.0404 \\
\hline Çakır & 0.0469 & 0.0528 & 0.0443 & 0.0473 & 0.0490 & 0.0595 \\
\hline Diyar & 0.0524 & 0.0466 & 0.0508 & 0.0487 & 0.0442 & 0.0469 \\
\hline Gülümser & 0.0514 & 0.0356 & 0.0496 & 0.0484 & 0.0454 & 0.0508 \\
\hline Hasanbey & 0.0446 & 0.0389 & 0.0454 & 0.0472 & 0.0544 & 0.0450 \\
\hline Ilgaz & 0.0483 & 0.0435 & 0.0477 & 0.0495 & 0.0519 & 0.0427 \\
\hline İnci & 0.0462 & 0.0372 & 0.0500 & 0.0493 & 0.0489 & 0.0547 \\
\hline İzmir & 0.0422 & 0.0499 & 0.0428 & 0.0453 & 0.0507 & 0.0494 \\
\hline Seçkin & 0.0490 & 0.0436 & 0.0476 & 0.0529 & 0.0448 & 0.0466 \\
\hline \multicolumn{7}{|c|}{ Adana in 2014 and 2015} \\
\hline Aksu & 0.0448 & 0.0430 & 0.0448 & 0.0441 & 0.0528 & 0.0400 \\
\hline Arda & 0.0492 & 0.0526 & 0.0504 & 0.0440 & 0.0503 & 0.0505 \\
\hline Aydın & 0.0519 & 0.0731 & 0.0511 & 0.0548 & 0.0432 & 0.0465 \\
\hline Azkan & 0.0466 & 0.0704 & 0.0518 & 0.0443 & 0.0465 & 0.0442 \\
\hline Çakır & 0.0469 & 0.0557 & 0.0416 & 0.0450 & 0.0460 & 0.0579 \\
\hline Diyar & 0.0552 & 0.0455 & 0.0507 & 0.0505 & 0.0446 & 0.0469 \\
\hline Gülümser & 0.0505 & 0.0231 & 0.0494 & 0.0463 & 0.0461 & 0.0548 \\
\hline Hasanbey & 0.0457 & 0.0314 & 0.0485 & 0.0447 & 0.0544 & 0.0443 \\
\hline Ilgaz & 0.0470 & 0.0329 & 0.0436 & 0.0506 & 0.0535 & 0.0399 \\
\hline İnci & 0.0466 & 0.0407 & 0.0510 & 0.0467 & 0.0483 & 0.0552 \\
\hline İzmir & 0.0449 & 0.0411 & 0.0480 & 0.0488 & 0.0487 & 0.0484 \\
\hline Seçkin & 0.0470 & 0.0416 & 0.0450 & 0.0556 & 0.0410 & 0.0448 \\
\hline \multicolumn{7}{|c|}{ Adana and Erzurum in 2015} \\
\hline Aksu & 0.0449 & 0.0273 & 0.0429 & 0.0464 & 0.0486 & 0.0387 \\
\hline Arda & 0.0492 & 0.0408 & 0.0530 & 0.0405 & 0.0488 & 0.0499 \\
\hline Aydın & 0.0510 & 0.0687 & 0.0479 & 0.0545 & 0.0430 & 0.0451 \\
\hline Azkan & 0.0435 & 0.0582 & 0.0480 & 0.0410 & 0.0462 & 0.0362 \\
\hline Çakır & 0.0508 & 0.0554 & 0.0470 & 0.0504 & 0.0501 & 0.0605 \\
\hline Diyar & 0.0490 & 0.0355 & 0.0471 & 0.0480 & 0.0427 & 0.0503 \\
\hline Gülümser & 0.0531 & 0.0340 & 0.0482 & 0.0479 & 0.0464 & 0.0468 \\
\hline Hasanbey & 0.0466 & 0.0471 & 0.0455 & 0.0465 & 0.0486 & 0.0461 \\
\hline Ilgaz & 0.0482 & 0.0515 & 0.0517 & 0.0502 & 0.0516 & 0.0454 \\
\hline İnci & 0.0480 & 0.0219 & 0.0507 & 0.0511 & 0.0499 & 0.0529 \\
\hline İzmir & 0.0396 & 0.0575 & 0.0425 & 0.0447 & 0.0518 & 0.0469 \\
\hline Seçkin & 0.0519 & 0.0559 & 0.0513 & 0.0538 & 0.0485 & 0.0536 \\
\hline
\end{tabular}


Tablo 3. Positive $\left(\mathrm{S}^{*}\right)$ and negative $\left(\mathrm{S}^{-}\right)$ideal solutions for the criteria

\begin{tabular}{ccccccc}
\hline \multirow{2}{*}{ Criteria } & \multicolumn{2}{c}{ All samples } & \multicolumn{2}{c}{ Adana 2014-2015 } & \multicolumn{2}{c}{ Adana-Erzurum 2015 } \\
\cline { 2 - 6 } & $\mathbf{S}^{*}$ & $\mathbf{S}^{-}$ & $\mathbf{S}^{*}$ & $\mathbf{S}^{-}$ & $\mathbf{S}^{*}$ & 0.040 \\
TPC & 0.053 & 0.042 & 0.055 & 0.045 & 0.053 & 0.022 \\
ICA & 0.071 & 0.036 & 0.073 & 0.023 & 0.069 & 0.042 \\
FRSA & 0.051 & 0.043 & 0.052 & 0.042 & 0.053 & 0.041 \\
WSPC & 0.055 & 0.043 & 0.056 & 0.044 & 0.055 & 0.043 \\
WBC & 0.054 & 0.044 & 0.054 & 0.041 & 0.052 & 0.036 \\
OBC & 0.059 & 0.038 & 0.058 & 0.040 & 0.061 & $\mathbf{S}^{-}$ \\
\hline
\end{tabular}

Tablo 4. TOPSIS evaluation of chickpea samples

\begin{tabular}{cccccccccc}
\hline Alternatives & \multicolumn{3}{c}{ All samples } & \multicolumn{3}{c}{ Adana 2014- 2015 } & \multicolumn{3}{c}{ Adana-Erzurum 2015 } \\
\hline & $\mathbf{d}_{\mathbf{i}}{ }^{* \mathbf{a}}$ & $\mathbf{d}_{\mathbf{i}}^{-\mathbf{b}}$ & $\mathbf{C}^{\mathbf{c}}$ & $\mathbf{d}_{\mathbf{i}}{ }^{*}$ & $\mathbf{d}_{\mathbf{i}}^{-}$ & $\mathbf{C}$ & $\mathbf{d}_{\mathbf{i}}{ }^{*}$ & $\mathbf{d}_{\mathbf{i}}^{-}$ & $\mathbf{C}$ \\
\hline Aksu & 0.0399 & 0.0085 & $1.75 \mathrm{E}-01$ & 0.0390 & 0.0233 & $3.75 \mathrm{E}-01$ & 0.0494 & 0.0115 & $1.89 \mathrm{E}-01$ \\
Arda & 0.0287 & 0.0214 & $4.27 \mathrm{E}-01$ & 0.0258 & 0.0341 & $5.69 \mathrm{E}-01$ & 0.0334 & 0.0280 & $4.56 \mathrm{E}-01$ \\
Aydın & 0.0171 & 0.0403 & $7.02 \mathrm{E}-01$ & 0.0164 & 0.0530 & $7.64 \mathrm{E}-01$ & 0.0186 & 0.0512 & $7.33 \mathrm{E}-01$ \\
Azkan & 0.0271 & 0.0261 & $4.91 \mathrm{E}-01$ & 0.0214 & 0.0489 & $6.95 \mathrm{E}-01$ & 0.0322 & 0.0371 & $5.35 \mathrm{E}-01$ \\
Çakır & 0.0224 & 0.0284 & $5.59 \mathrm{E}-01$ & 0.0257 & 0.0377 & $5.95 \mathrm{E}-01$ & 0.0154 & 0.0449 & $7.44 \mathrm{E}-01$ \\
Diyar & 0.0299 & 0.0198 & $3.98 \mathrm{E}-01$ & 0.0317 & 0.0282 & $4.71 \mathrm{E}-01$ & 0.0372 & 0.0234 & $3.86 \mathrm{E}-01$ \\
Gülümser & 0.0381 & 0.0177 & $3.17 \mathrm{E}-01$ & 0.0519 & 0.0187 & $2.65 \mathrm{E}-01$ & 0.0386 & 0.0233 & $3.76 \mathrm{E}-01$ \\
Hasanbey & 0.0374 & 0.0137 & $2.67 \mathrm{E}-01$ & 0.0464 & 0.0178 & $2.77 \mathrm{E}-01$ & 0.0291 & 0.0293 & $5.02 \mathrm{E}-01$ \\
Ilgaz & 0.0332 & 0.0155 & $3.18 \mathrm{E}-01$ & 0.0459 & 0.0174 & $2.75 \mathrm{E}-01$ & 0.0238 & 0.0360 & $6.02 \mathrm{E}-01$ \\
İnci & 0.0357 & 0.0199 & $3.58 \mathrm{E}-01$ & 0.0354 & 0.0263 & $4.27 \mathrm{E}-01$ & 0.0478 & 0.0241 & $3.35 \mathrm{E}-01$ \\
İzmir & 0.0290 & 0.0193 & $4.00 \mathrm{E}-01$ & 0.0363 & 0.0228 & $3.85 \mathrm{E}-01$ & 0.0265 & 0.0385 & $5.92 \mathrm{E}-01$ \\
Seçkin & 0.0322 & 0.0172 & $3.48 \mathrm{E}-01$ & 0.0382 & 0.0228 & $3.74 \mathrm{E}-01$ & 0.0151 & 0.0435 & $7.42 \mathrm{E}-01$ \\
\hline
\end{tabular}

${ }^{\mathrm{a}} \mathbf{d}_{\mathbf{i}}{ }^{*},{ }^{\mathrm{b}} \mathbf{d}_{\mathbf{i}}{ }^{-}$, and ${ }^{\mathbf{c}} \mathbf{C}$ are positive ideal solution of Euclidean distance, negative ideal solution of Euclidean distance, and the closeness coefficient of each alternative, respectively.

\section{Correlations Between Determined Parameters}

Correlation analyses between determined parameters of chickpea cultivars were done in three groups; cultivars grown in i) only Adana region, ii) in 2015, iii) all location and harvest years (Table 5). In each group, there were significant positive correlations between TPC, FRSA, and ICA but no significant correlations were between $\mathrm{WBC}$ and $\mathrm{OBC}$ $(\mathrm{P}<0.05)$. The significant correlations between TPC and ICA were low as 0.195 (for all samples) or 0.233 (harvested in Adana region) and between TPC and FRSA were moderate as 0.577 (for all extracts) or 0.539 (harvested in Adana region) or 0.492 (harvested in 2015). Correlation analysis showed that the compounds with free radical scavenging activities could have iron chelating activities, but these two properties were not very associated to each other. These ac- tivities are mostly generated by soluble proteins in the extracts because it is known that soluble chickpea proteins have both free radical scavenging and iron chelating activities (Arcan and Yemenicioglu, 2007). Moreover, soluble free phenolics in the extracts are greatly contributed to the free radical scavenging activities. In all groups, WBC and OBC were negatively or almost zero correlated with TPC, FRSA, or ICA either significant or not. This indicated that the seeds with high antioxidant activity may have poor functional properties. Functional properties are mostly related to the carbohydrate and protein content which had the ability to bound water and oil and most of these contents were mostly eliminated during water soluble extraction process. Therefore, there could not be found any correlation between the bioactive and functional properties of the extracts. 
Table 5. Correlations between different parameters determined for chickpea cultivars

\begin{tabular}{|c|c|c|c|c|c|}
\hline \multicolumn{6}{|c|}{ All samples } \\
\hline & TPC $^{\mathbf{a}}$ & ICA & FRSA & WSPC & WAC \\
\hline $\mathbf{I C A}^{\mathrm{b}}$ & $0.195^{*}$ & & & & \\
\hline FRSA $^{c}$ & $0.577^{*}$ & $0.245^{*}$ & & & \\
\hline WSPC $^{d}$ & $0.255^{*}$ & $0.200 *$ & 0.152 & & \\
\hline $\mathbf{W A C}$ & $-0.217^{*}$ & -0.100 & $-0.285^{*}$ & -0.093 & \\
\hline $\mathbf{O A C} \mathbf{C}^{\mathbf{f}}$ & -0.028 & 0.068 & 0.074 & 0.109 & -0.154 \\
\hline \multicolumn{6}{|c|}{ Adana 2014-2015 } \\
\hline & TPC & ICA & FRSA & WSPC & WAC \\
\hline ICA & $0.233^{*}$ & & & & \\
\hline FRSA & $0.539 *$ & $0.410^{*}$ & & & \\
\hline WSPC & 0.188 & $0.239 *$ & 0.104 & & \\
\hline WAC & -0.192 & -0.179 & $-0.220 * *$ & -0.113 & \\
\hline OAC & 0.064 & 0.113 & 0.046 & 0.150 & -0.301 \\
\hline \multicolumn{6}{|c|}{ Adana-Erzurum in 2015} \\
\hline & TPC & ICA & FRSA & WSPC & WAC \\
\hline ICA & -0.054 & & & & \\
\hline FRSA & $0.492 *$ & 0.025 & & & \\
\hline WSPC & $0.215^{* *}$ & 0.192 & 0.182 & & \\
\hline WAC & $-0.312 *$ & -0.183 & $-0.287 *$ & $-0.229 * *$ & \\
\hline OAC & 0.086 & -0.005 & 0.055 & $0.205^{* *}$ & -0.029 \\
\hline
\end{tabular}

$* \mathrm{P}<0.05, * * \mathrm{P}<0.1$

${ }^{a}$ TPC: Total phenolic content (mg GAE/g), ${ }^{b} \mathrm{ICA}$ : Iron chelating activity ( $\mu$ molEDTA/g), ${ }^{\mathrm{c}}$ FRSA: Free radical scavenging activity $(\mu \mathrm{mol}$ trolox/g), ${ }^{\mathrm{d}}$ WSPC: Water soluble protein content (mg caseinate $\left./ \mathrm{g}\right),{ }^{e}$ WAC: Water absorption capacity $(\mathrm{g} / \mathrm{g}),{ }^{\mathrm{f}} \mathrm{OAC}$ : Oil absorption capacity $(\mathrm{g} / \mathrm{g})$

\section{Conclusions}

This study revealed that for ranking of the alternatives, TOPSIS is suitable technique to be used in multi criteria decision making process when the sample size is big, and the determined parameters related to the same property are existed. 12 registered cultivars grown in different location and year studied for their functional properties and their potential to be processed as value added bioactive or functional product was highlighted for the first time. However, the individual cultivars had varying results by different harvest locations and years, they had similar average values when they grouped as the same location or year. This situation showed that the chickpeas could have those potentials independent from their harvest location and year. For this reason, the chickpeas studied in this study are suitable legumes which can be used for functional food additives due to their good techno-functional and bioactive properties. They also have potential to be used as functional plant protein sources for different purposes in food, pharmaceutical and cosmetic industries which extensively benefited from plant sourced natural products. After more detailed phenolic, protein and mineral characterization of chickpea cultivars grown in different location and year in Turkey, the effects of growing conditions on functional and bioactive properties of cultivars will also be determined.

\section{Compliance with Ethical Standard}

Conflict of interests: The authors declare that for this article they have no actual, potential or perceived the conflict of interests.

Financial disclosure: This study was supported by Adana Science and Technology University Scientific Research Coordination Unit. Project Number MÜHDBF.GIDA.2015-14.

Ethics committee approval: No ethics committee approval is needed. 


\section{References}

Ansarifar, E., Shahidi, F., Mohebbi, M., Razavi, S.M., and Ansarifar, J. (2015). A new technique to evaluate the effect of chitosan on properties of deep-fried Kurdish cheese nuggets by TOPSIS. LWT-Food Science and Technology, 62(2), 1211-1219.

https://doi.org/10.1016/j.lwt.2015.01.051

Arab, E.A.A., Helmy, I.M.F., Bareh, G.F. (2010). Nutritional Evaluation and Functional Properties of Chickpea (Cicer arietinum L.) Flour and the Improvement of Spaghetti. Journal of American Science, 6(10), 1055-1072.

Arcan, I., Yemenicioglu, A. (2007). Antioxidant activity of protein extracts from heat-treated or thermally processed chickpeas and white beans. Food Chemistry, 103(2), 301312.

https://doi.org/10.1016/j.foodchem.2006.07.050

Arcan, I., Yemenicioglu, A. (2010). Effects of controlled pepsin hydrolysis on antioxidant potential and fractional changes of chickpea proteins. Food Research International, 43(1), 140-147.

https://doi.org/10.1016/j.foodres.2009.09.012

Atalay, E., Babaoglu, M. (2012). Determination of Genetic Relationship in Turkish Chickpea (Cicer Arietinum L.) Genotypes Using Ssr Molecular Markers and Capillary Electrophoresis. The Journal of Animal \& Plant Sciences, 22(2), 369-375.

Aydemir, L.Y., Gökbulut, A.A., Baran, Y., Yemenicioğlu, A. (2014). Bioactive, functional and edible film-forming properties of isolated hazelnut (Corylus avellana L.) meal proteins. Food Hydrocolloids, 36, 130-142.

https://doi.org/10.1016/j.foodhyd.2013.09.014

Aydemir, L.Y., Yemenicioglu, A. (2013). Potential of Turkish Kabuli type chickpea and green and red lentil cultivars as source of soy and animal origin functional protein alternatives. LWT-Food Science and Technology, 50(2), 686-694. https://doi.org/10.1016/j.lwt.2012.07.023

Balli, S., Korukoglu, S. (2009). Opearating system selection using fuzzy AHP and TOPSIS methods. Mathematical and Computational Applications, 14(2), 119-130. https://doi.org/10.3390/mca14020119

Bibi, N., Khattak, A.B., Khattak, G.S.S., Mehmood, Z., Ihsanullah, I. (2007). Quality and consumers acceptability studies and their inter-relationship of newly evolved desi type chickpea genotypes (Cicer arietinum L.). Quality evolution of new chickpea genotypes. International Journal of Food Science and Technology, 42(5), 528-534.

https://doi.org/10.1111/j.1365-2621.2006.01246.x

Çelik, İ., Işık, F., Yılmaz, Y. (2016). Effect of roasted yellow chickpea (Leblebi) flour addition on chemical, rheological and sensory properties of Boza. Journal of Food Processing and Preservation, 40(6), 1400-1406.

https://doi.org/10.1111/jfpp.12725

Coşkuner, Y., Karababa, E. (2004). Leblebi: a roasted chickpea product as a traditional Turkish snack food. Food Reviews International, 20(3), 257-274.

https://doi.org/10.1081/FRI-200029424

Dıblan, S., Kadiroğlu, P., Aydemir, L.Y. (2018). FT-IR spectroscopy characterization and chemometric evaluation of legumes extracted with different solvents. Food and Health, $4(2), 80-88$

https://doi.org/10.3153/FH18008

Dogan, M., Aslan, D., Aktar, T., Goksel Sarac, M. (2016). A methodology to evaluate the sensory properties of instant hot chocolate beverage with different fat contents: multi-criteria decision-making techniques approach. European Food Research and Technology, 242(6), 953-966. https://doi.org/10.1007/s00217-015-2602-z

Dogan, M., Aslan, D., Ozgur, A. (2018). Bioactive and sensorial characteristics of the milk based herbal (Rumex crispus L.) tea: multi-criteria decision making approach. Journal of Food Measurement and Characterization, 12(1), 535-544. https://doi.org/10.1007/s11694-017-9665-4

Durante, M., Lenucci, M.S., Mita, G. (2014). Supercritical carbon dioxide extraction of carotenoids from pumpkin ( $\mathrm{C} u$ curbita spp.): A review. International Journal of Molecular Sciences, 15(4), 6725-6740.

https://doi.org/10.3390/ijms15046725

PMid:24756094 PMCid:PMC4013658 
Escarpa, A., Gonzalez, M.C. (2001). Total extractable phenolic chromatographic index: an overview of the phenolic class contents from different sources of foods. European Food Research and Technology, 212, 439-444.

https://doi.org/10.1007/s002170000269

FAO (2012). World Lentil Production.

http://www.fao.org/faostat/en/\#data/QC

(accessed 16.07.2019)

Gul, O., Dervisoglu, M. (2017). Application of multicriteria decision technique to determine optimum sodium alginate concentration for microencapsulation of Lactobacillus casei Shirota by extrusion and emulsification. Journal of Food Process Engineering, 40(3), e12481.

https://doi.org/10.1111/jfpe.12481

Gurmeric, V.E., Dogan, M., Toker, O.S., Senyigit, E., Ersoz, N.B. (2013). Application of different multi-criteria decision techniques to determine optimum flavour of prebiotic pudding based on sensory analyses. Food and Bioprocess Technology, 6(10), 2844-2859.

https://doi.org/10.1007/s11947-012-0972-9

Hou, F., Su, D., Xu, J., Gong, Y., Zhang, R., Wei, Z., Chi, J., Zhang, M. (2016). Enhanced extraction of phenolics and antioxidant capacity from Sorghum (Sorghum bicolor L. Moench) shell using ultrasonic-assisted ethanol-water binary solvent. Journal of Food Processing and Preservation, 40(6), 1171-1179.

https://doi.org/10.1111/jfpp.12699

Jogihalli, P., Singh, L., Sharanagat, V.S. (2017). Effect of microwave roasting parameters on functional and antioxidant properties of chickpea (Cicer arietinum). LWT-Food Science and Technology, 79, 223-233.

https://doi.org/10.1016/j.lwt.2017.01.047

Joshi, A.U., Liu, C., Sathe, S.K., Jogihalli, P., Singh, L., Kumar, K., Sharanagat, V.S., Xu, B.J., Yuan, S.H., Chang, S.K.C., Withana-Gamage, T.S., Wanasundara, J.P., Pietrasik, Z., Shand, P.J., Alvarez, M.D., Herranz, B., Fuentes, R., Cuesta, F.J., Canet, W., Maninder, K., Sandhu, K.S., Singh, N. (2007). Functional properties of select seed flours. Food Chemistry, 60(1), 325-331.

https://doi.org/10.1016/j.lwt.2014.08.038
Kaur, M., Singh, N. (2005). Studies on functional, thermal and pasting properties of flours from different chickpea (Cicer arietinum L.) cultivars. Food Chemistry, 91(3), 403411.

https://doi.org/10.1016/j.foodchem.2004.06.015

Kou, X., Chen, Q., Li, X., Li, M., Kan, C., Chen, B., Zhang, Y., Xue, Z. (2015). Quantitative assessment of bioactive compounds and the antioxidant activity of 15 jujube cultivars. Food Chemistry, 173, 1037-1044.

https://doi.org/10.1016/j.foodchem.2014.10.110

PMid:25466122

Kou, X., Gao, J., Zhang, Z., Wang, H., Wang, X. (2013). Purification and identification of antioxidant peptides from chickpea (Cicer arietinum L.) albumin hydrolysates. LWTFood Science and Technology, 50(2), 591-598.

https://doi.org/10.1016/j.1wt.2012.08.002

Lin, M.C., Wang, C.C., Chen, M.S., Chang, C.A. (2008). Using AHP and TOPSIS approaches in customer-driven product design process. Computers in Industry, 59(1), 17-31. https://doi.org/10.1016/j.compind.2007.05.013

Lowry, O.H., Rosebrough, N.J., Farr, A.L., Randall, R.J. (1951). Protein measurement with the folin phenol reagent. Journal of Biological Chemistry, 193(1), 265-275.

Mafakheri, A., Siosemardeh, A., Bahramnejad, B., Struik, P. C., Sohrabi, Y. (2011). Effect of drought stress and subsequent recovery on protein, carbohydrate contents, catalase and peroxidase activities in three chickpea (cicer arietinum) cultivars. Australian Journal of Crop Science, 5(10), 1255-1260.

Mokni Ghribi, A., Maklouf Gafsi, I., Sila, A., Blecker, C., Danthine, S., Attia, H., Bougatef, A., Besbes, S. (2015). Effects of enzymatic hydrolysis on conformational and functional properties of chickpea protein isolate. Food Chemistry, 187, 322-330.

https://doi.org/10.1016/j.foodchem.2015.04.109

PMid:25977033 
Neugschwandtner, R.W., Wagentristl, H., Kaul, H.P. (2015). Nitrogen yield and nitrogen use of chickpea compared to pea, barley and oat in Central europe. International Journal of Plant Production, 9(2), 291-303.

Oweis, T., Hachum, A., Pala, M. (2004). Water use efficiency of winter-sown chickpea under supplemental irrigation in a mediterranean environment. Agricultural Water Management, 66(2), 163-179.

https://doi.org/10.1016/j.agwat.2003.10.006

Özcan, T., Elebi, N., and Esnaf, A. (2011). Comparative analysis of multi-criteria decision making methodologies and implementation of a warehouse location selection problem. Expert Systems with Applications, 38(8), 9773-9779.

https://doi.org/10.1016/j.eswa.2011.02.022

Özer, S., Karaköy, T., Toklu, F., Baloch, F.S., Kilian, B., Özkan, H. (2010). Nutritional and physicochemical variation in Turkish kabuli chickpea (Cicer arietinum L.) landraces. Euphytica, 175(2), 237-249.

https://doi.org/10.1007/s10681-010-0174-3

Ozkilinc, H., Frenkel, O., Shtienberg, D., Abbo, S., Sherman, A., Kahraman, A., Can, C. (2011). Aggressiveness of eight Didymella rabiei isolates from domesticated and wild chickpea native to Turkey and Israel, a case study. European Journal of Plant Pathology, 131(3), 529-537.

https://doi.org/10.1007/s10658-011-9828-9

Ozturk, G., Dogan, M., and Said Toker, O. (2014). Physicochemical, functional and sensory properties of mellorine enriched with different vegetable juices and TOPSIS approach to determine optimum juice concentration. Food Bioscience, 7, 45-55.

https://doi.org/10.1016/j.fbio.2014.05.001

Re, R., Pellegrini, N., Proteggente, A., Pannala, A., Yang, M., Rice-Evans, C. (1999). Antioxidant activity applying an improved ABTS radical cation decolorization assay. Free Radical Biology and Medicine, 26(9-10), 1231-1237. https://doi.org/10.1016/S0891-5849(98)00315-3
Rocchetti, G., Chiodelli, G., Giuberti, G., Masoero, F., Trevisan, M., Lucini, L. (2017). Evaluation of phenolic profile and antioxidant capacity in gluten-free flours. Food Chemistry, 228, 367-373.

https://doi.org/10.1016/j.foodchem.2017.01.142

PMid:28317736

Sadras, V., Dreccer, M.F. (2015). Adaptation of wheat, barley, canola, field pea and chickpea to the thermal environments of Australia. Crop and Pasture Science, 66(11), 11371150 .

https://doi.org/10.1071/CP15129

Siddique, K.H.M., Johansen, C., Turner, N.C., Jeuffroy, M.H., Hashem, A., Sakar, D., Gan, Y., Alghamdi, S.S. (2012). Innovations in agronomy for food legumes. A review. Agronomy for Sustainable Development, 32(1), 45-64.

https://doi.org/10.1007/s13593-011-0021-5

Sreerama, Y.N., Sashikala, V.B., Pratape, V.M. (2012). Phenolic compounds in cowpea and horse gram flours in comparison to chickpea flour: Evaluation of their antioxidant and enzyme inhibitory properties associated with hyperglycemia and hypertension. Food Chemistry, 133(1), 156-162. https://doi.org/10.1016/j.foodchem.2012.01.011

Sun, Y.F., Liang, Z.S., Shan, C.J., Viernstein, H., Unger, F. (2011). Comprehensive evaluation of natural antioxidants and antioxidant potentials in Ziziphus jujuba Mill. var. spinosa (Bunge) Hu ex H. F. Chou fruits based on geographical origin by TOPSIS method. Food Chemistry, 124(4), 16121619.

https://doi.org/10.1016/j.foodchem.2010.08.026

Torres-Fuentes, C., Contreras, M.D.M., Recio, I., Alaiz, M., Vioque, J. (2015). Identification and characterization of antioxidant peptides from chickpea protein hydrolysates. Food Chemistry, 180, 194-202.

https://doi.org/10.1016/j.foodchem.2015.02.046

PMid:25766818 
Torutaeva, E., Asanaliev, A., Prieto-Linde, M.L., Zborowska, A., Ortiz, R., Bryngelsson, T., Garkava-Gustavsson, L. (2014). Evaluation of microsatellite-based genetic diversity, protein and mineral content in chickpea accessions grown in Kyrgyzstan. Hereditas, 151(4-5), 81-90.

https://doi.org/10.1111/hrd2.00042

PMid:25363275

Xu, Y., Obielodan, M., Sismour, E., Arnett, A., Alzahrani, S., Zhang, B. (2017). Physicochemical, functional, thermal and structural properties of isolated Kabuli chickpea proteins as affected by processing approaches. International Journal of Food Science and Technology, 52(5), 1147-1154.

https://doi.org/10.1111/ijfs.13400

Xu, Y., Thomas, M., Bhardwaj, H.L. (2014). Chemical composition, functional properties and microstructural char acteristics of three kabuli chickpea (Cicer arietinum L.) as affected by different cooking methods. International Journal of Food Science and Technology, 49(4), 1215-1223. https://doi.org/10.1111/ijfs.12419

Yust, M. del M., Pedroche, J., Millán-Linares, M. del C., Alcaide-Hidalgo, J.M., Millán, F. (2010). Improvement of functional properties of chickpea proteins by hydrolysis with immobilised Alcalase. Food Chemistry, 122(4), 1212-1217. https://doi.org/10.1016/j.foodchem.2010.03.121

Zhao, Y., Du, S., Wang, H., Cai, M. (2014). In vitro antioxidant activity of extracts from common legumes. Food Chemistry, 152, 462-466.

https://doi.org/10.1016/j.foodchem.2013.12.006

PMid:24444962 